\title{
Role of Uric Acid in Semen
}

\author{
Saleem Ali Banihani
}

Department of Medical Laboratory Sciences, Jordan University of Science and Technology, Irbid 22110, Jordan; sabanihani@just.edu.jo; Tel.: +962-2-720-1000

Received: 28 June 2018; Accepted: 26 July 2018; Published: 31 July 2018

\begin{abstract}
Since 1963, various research studies and reports have demonstrated the role of uric acid (2,6,8-trihydroxypurine), an end product of adenosine and guanosine catabolism, on semen quality and sperm function. However, this effect has not yet been collectively discussed, even though uric acid has been a well-recognized constituent in semen. Here, we systematically and comprehensively discuss and summarize the role/effect of uric acid in semen quality by searching the main databases for English language articles considering this topic. Additionally, certain significant and relevant papers were considered to support discussions and perceptions. In conclusion, uric acid contributes to maintaining and enhancing sperm motility, viability, and morphology; therefore, protecting sperm function and fertilizing ability. This contribution is performed mainly by neutralizing the damaging effect of oxidizing (e.g., endogenous free radicals and exogenous toxins) and nitrating agents and enhancing certain bioactive enzymes in spermatozoa. In contrast, high levels of uric acid may induce adverse effects to sperm function, at least in part, by reducing the activity of vital enzymes in spermatozoa. However, further research, mainly clinical, is still required to fully explore the role/effect of uric acid in semen.
\end{abstract}

Keywords: uric acid; sperm; semen quality; antioxidant

\section{Introduction}

Uric acid $\left(\mathrm{C}_{5} \mathrm{H}_{4} \mathrm{~N}_{4} \mathrm{O}_{3} ; 2,6,8\right.$-trihydroxypurine), an inert heterocyclic molecule (Figure 1$)$, is the end product of purine nucleotides (guanosine and adenosine) catabolism in humans and higher primates [1]. Mammals and lower primates other than humans carry purine catabolism one step further with the formation of allantoin from urate, a step catalyzed by uricase, which is an oxidoreductase enzyme [2]. At physiologic $\mathrm{pH}$, uric acid is usually presents as its monoanion urate, which is neutralized by sodium cations. Among the total non-protein nitrogen compounds in human plasma and urine, urate forms approximately $10 \%$, and $1.7 \%$, respectively [3].

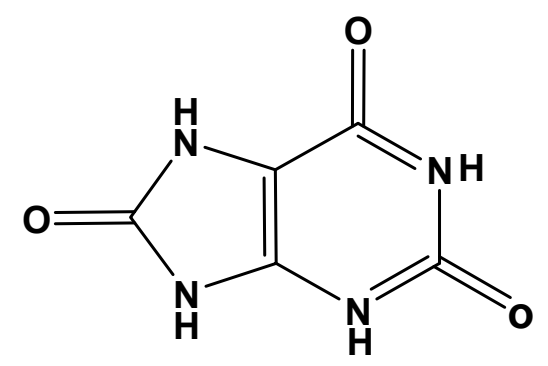

Figure 1. Chemical structure of uric acid.

In the human body, at $37^{\circ} \mathrm{C}$ and $7.4 \mathrm{pH}$, urate is relatively soluble; therefore, supersaturation of sodium urate in the blood leads to its crystallization and precipitation in joints. This precipitation may 
lead to a form of inflammatory arthritis known as "gout". Usually, such conditions can occur because of excess dietary protein intake, underexcretion of urate by the kidney, and inherited metabolic disorders.

Various studies have shown that uric acid is a potent antioxidant, capable particularly of neutralizing hydroxyl radicals $\left({ }^{\bullet} \mathrm{OH}\right)$ and hypochlorous acid $(\mathrm{HOCl})$, before it is converted to innocuous products such as allantoin, glyoxylate, allantoate, urea, and oxalate [1]. In addition, urate was found to serve as a coenzyme for certain oxygenase enzymes. Moreover, interestingly, studies have shown that urates prevent inactivation of certain endothelial enzymes such as angiotensin-converting enzyme and cyclooxygenase enzyme [1].

Since 1963, various studies (direct, indirect, basic, and clinical) have revealed the role of uric acid in semen quality; this role, though, has yet to be collectively summarized. Here, we systematically and comprehensively discuss and summarize the role/effect of uric acid on semen quality. To undertake this, we searched the PubMed, Scopus, and Web of Science databases for English language papers (fully-published or abstracts) from July 1963 to June 2018 using the key words "uric acid" or "urate" vs. "sperm". In addition, certain significant and relevant papers were considered to support the observed mechanistic perceptions and discussions.

\section{Uric Acid as a Component of Semen}

In general, non-protein nitrogen compounds, including uric acid, are present in semen [4-6]. They are possibly derived from two sources: transudation from the blood circulation [4] or local production [4,7]. In bulls, urate is probably produced by oxidation of xanthine and hypoxanthine in the seminal vesicles [8]. In certain cases, such as retrograde ejaculation, the sperm come into direct contact with uric acid present in urine, which might increase to toxic concentrations [4].

A number of animal studies revealed that certain physical, social, and environmental factors may influence the level of seminal urate. For example, a study on cockerels showed that the concentration of uric acid in seminal plasma may be affected by the semen collection method [9]. In addition, the mean value of seminal urate was found to be higher in younger bulls compared to old ones [10]. Moreover, uric acid in semen was found to be affected by temperature; its level was found to be higher in cold conditions compared to warm conditions [10].

Alternatively, in vitro short-term storage of sterlet (Acipenser ruthenus) semen, at $4{ }^{\circ} \mathrm{C}$ for $36 \mathrm{~h}$, was found not to change the level and the bioactivity of uric acid [11]. Also, uric acid was unaffected by restricted diet in male collared peccaries [12].

Urate displayed approximately equal or slightly elevated concentrations compared with serum [13]. The concentration ratio of serum urate to seminal plasma urate is approximately one [13]. The content of urate in seminal plasma in normozoospermia $(n=44)$, oligozoospermic $(n=19)$, and azoospermic $(n=10)$ men were $0.47 \pm 0.13 \mathrm{mmol} \mathrm{L}^{-1}, 0.48 \pm 0.23 \mathrm{mmol} \mathrm{L}^{-1}$, and $0.45 \pm 0.14 \mathrm{mmol} \mathrm{L}^{-1}$, respectively [13].

\section{The Antioxidant Activity of Uric Acid in Semen}

Urate is one of the major antioxidants in human semen, and its antioxidant activity in semen contributes almost half as much as ascorbate [14]. It has been shown that the antioxidant activity of uric acid against reactive oxygen species is mostly restricted to the semen, with little activity in the epididymis [14]. Various components of seminal plasma, including urate, contribute to its fast total radical-trapping antioxidant potential. It has been shown that $37 \%$ of the antioxidant activity in semen is attributed only to ascorbate, urate, and tyrosine [15]. In other species such as brown trout, a European species of salmonid fish, urate was found to be the main seminal antioxidant [16].

Lower levels of urate might be considered as a toxicity marker from exogenous oxidants such as methyl parathion, an organophosphorus pesticide, in testis [17,18], epididymis [19,20], and seminal plasma [21]. In addition, it has been shown that the lower urate concentrations found in seminal fluid of infertile patients might be indicative of decreased anti-oxidative protection, which could be dangerous to sperm integrity [22]. 


\section{Effect of Uric Acid on Sperm Parameters}

Table 1 summarizes the research studies that reveal the direct effects of uric acid on semen quality and sperm parameters. Almost all main sperm parameters such as motility, count, morphology, and DNA damage are significantly affected by seminal uric acid, showing improved sperm parameters at normal and even at higher seminal uric acid concentrations. In contrast, urate crystals were detected in semen of a patient with symptoms of chronic prostatitis, and these crystals could be behind the observed sperm abnormalities [23].

Table 1. Studies that demonstrate the direct effect of uric acid on semen and sperm parameters.

\begin{tabular}{|c|c|c|c|c|}
\hline Affecter & Type of Study & $\begin{array}{c}\text { Study } \\
\text { Population/Sample }\end{array}$ & Effect on Sperm Parameters & Ref. \\
\hline Uric acid & In vitro & Human sperm & (+) Sperm motility & [4] \\
\hline Urate at $400 \mu \mathrm{M}$ & In vitro & Human sperm & (-) X-ray-induced sperm DNA damage & [24] \\
\hline (+) Seminal uric acid & Observational & Human semen and sperm & 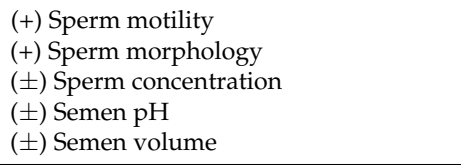 & [25] \\
\hline $\begin{array}{l}\text { Uric acid at }(0.25, \\
\left.0.5 / 5-7 \times 10^{7} \text { cells } \mathrm{mL}^{-1}\right)\end{array}$ & In vitro & Brown trout semen & $\begin{array}{l}\text { (+) Sperm membrane integrity } \\
(+) \text { Sperm motility } \\
(-) \text { Sperm lipid peroxidation }\end{array}$ & [16] \\
\hline (+) Seminal uric acid & Observational & Sub-fertile men & $\begin{array}{l}\text { ( } \pm \text { Semen volume } \\
( \pm) \text { Sperm count } \\
( \pm) \text { Sperm motility }\end{array}$ & [26] \\
\hline Uric acid at $0.25 \mathrm{mmol} \mathrm{L}^{-1}$ & In vitro & $\begin{array}{l}\text { Cryopreservation } \\
\text { extenders of rainbow trout }\end{array}$ & (+) Sperm motility & [27] \\
\hline (+) Seminal uric acid & Observational & Human semen & (+) Sperm concentration & [28] \\
\hline
\end{tabular}

$(-)$ decrease; $(+)$ increase; $( \pm)$ no effect.

Various research studies have investigated the level of uric acid in different infertile men groups. It was found that mean concentrations of uric acid for normal men are higher than for those men with azoospermia and oligozoospermia [28]. In addition, among the infertile groups, azoospermic men had the lowest seminal uric acid levels [29]. Also, normozoospermic patients had lower urate concentrations $(320 \pm 22 \mu \mathrm{M})$ compared with healthy donors $(426 \pm 26 \mu \mathrm{M})$ [22]. This evidence, in general, shows that urate levels in seminal plasma are lower in infertile men compared to that of fertile men.

\section{Mechanistic Studies}

The role of uric acid in preserving and/or improving sperm parameters such as motility, viability, morphology, and DNA integrity, and hereafter increasing the fertilizing ability of sperm, is due principally to its antioxidant potential.

Sperm generate small amounts of nitric oxide (NO) and superoxide ion $\left(\mathrm{O}_{2}{ }^{\bullet-}\right)$. The reaction between these two radical species results in formation of peroxynitrite $\left(\mathrm{ONOO}^{-}\right)$[30]. This reaction is very fast $\left(6.7 \times 10^{9} \mathrm{~mol} \mathrm{~s}^{-1}\right)$ and irreversible due to its exothermic nature [30,31]. Peroxynitrite is a strong oxidizing and/or nitrating agent [32,33]. It can attack all main biomolecules (DNA, proteins, lipids) in sperm [34,35]. In addition, $\mathrm{ONOO}^{-}$may react with the tyrosine moieties in any given cellular protein and form 3-nitrotyrosine, a nitrated product and biomarker [33]. Such oxidation and/or nitration reactions may lead to sperm injury and sperm death [35]. Uric acid was found to be the most effective scavenger of $\mathrm{ONOO}^{-}$in spermatozoa, which enhances its function, and hence the fertilizing capability [36,37].

Moreover, the hydroxyl radical $\left(\bullet^{\bullet} \mathrm{OH}\right)$ and $\mathrm{O}_{2}{ }^{\bullet-}$ were found to reduce human sperm motility [38], viability [39], and morphology [40]. In cellular systems, ${ }^{\bullet} \mathrm{OH}$ is generated from hydrogen peroxide $\left(\mathrm{H}_{2} \mathrm{O}_{2}\right)$ when reacted with $\mathrm{O}_{2}{ }^{\bullet-}$ in the presence of reduced forms of metal ions such as ferrous $\left(\mathrm{Fe}^{2+}\right)$ and cuprous $\left(\mathrm{Cu}^{+}\right)$ions [41-43]; such reactions are known as Fenton's reactions. Studies demonstrated 
that urate is able to scavenge both ${ }^{\bullet} \mathrm{OH}$ and $\mathrm{O}_{2}{ }^{\bullet-}$ radicals and protect against oxidative damage, particularly DNA damage and lipid peroxidation [44-46]; thus, enhancing sperm function, and consequently the fertilizing ability.

Other important functions for seminal uric acid is that it enhances certain bioactive enzymes that are considered crucial for adequate sperm function.

Cyclooxygenase, also called prostaglandin-endoperoxide synthase, is an enzyme responsible for synthesis of prostanoids such as prostaglandins and thromboxane. Cyclooxygenase 1 (COX-1) and cyclooxygenase 2 (COX-2) isoforms are present in human semen and involved in sperm function and the fertilization process [47]. It has been shown that urate serves as a coenzyme for cyclooxygenase [1]. Studies have revealed that urate, at its physiological level, prevents oxidative inactivation of cyclooxygenase [1,48]. Accordingly, this may be valuable to enhance sperm function and fertilization rate. In fact, urate was found to have a role in the conversions from biologically inactive precursors into active prostaglandin derivatives in the accessory organs of reproduction $[7,13,49]$.

In contrast, nitric oxide, a free radical gas, is produced from L-arginine by a class of enzymes known as nitric oxide synthases (NOS) [50]. It has been shown that a NOS similar to endothelial nitric oxide synthase (eNOS) and brain nitric oxide synthase (bNOS) are present in human spermatozoa [50]. Nitric oxide was found to be crucial for adequate motility of human spermatozoa [51-53]. Therefore, decreased levels of nitric oxide, below normal, reduce sperm motility [54]. High concentrations of urate (12 mg dL $\mathrm{m}^{-1}$, for $24 \mathrm{~h}$ treatment) significantly attenuated eNOS activity, and thus nitric oxide production in human umbilical vascular endothelial cells by decreasing the binding between calmodulin and eNOS [55]. Accordingly, it is acceptable to suggest that high levels of uric acid in human semen may reduce sperm motility and function, and direct experimental studies to approve this suggestion seem valuable.

In addition, adenosine triphosphate (ATP) is generated in human spermatozoa from the chemical shuttle between creatine, a nitrogenous organic acid synthesized in the liver from the amino acids arginine and glycine, and creatine phosphate, which is catalyzed by creatine phosphokinase (CPK), also called creatine kinase (CK) [56]. High concentration of urate $\left(\sim 6.8 \mathrm{mmol} \mathrm{L}^{-1}\right)$ was found to inhibit all isoforms of creatine kinase (CK-MM, CK-MB, CK-BB) and may be by affecting the SH groups of the enzyme $[57,58]$. Therefore, high concentrations of urate in semen may decrease sperm function, particularly sperm motility, by inhibiting the activity of CK, and as a result, reducing the normal levels of chemical energy produced. It is important to point out that the increased levels of uric acid in semen is an abnormal condition that occurs only at certain occasions such as retrograde ejaculation, when the sperm come into direct contact with uric acid present in urine, or maybe in the presence of very high levels of uric acid in the blood, which is not yet completely approved [4].

The correlation between uric acid and other bioactive molecules/ions in semen was explored. For example, urate displayed inverse relationships against seminal fructose [13]. In addition, seminal urate and xanthine correlated significantly to each other in oligozoospermic and normal men [13].

Moreover, healthy fertile men with high magnesium concentrations $\left(3.43 \pm 1.77 \mathrm{mmol} \mathrm{L}^{-1}\right)$ had lower seminal uric acid levels compared to those with low magnesium concentrations $\left(1.53 \pm 0.39 \mathrm{mmol} \mathrm{L}^{-1}\right)$ [59]. The possible explanation for such correlation is that higher magnesium concentrations may enhance sperm metabolism resulting in increased production of reactive oxygen species [59]. These pro-oxidants oxidize uric acid and decrease its antioxidant activity. Indeed, total antioxidant capacity was found to be lower in men with high seminal magnesium concentrations compared to those with low magnesium concentrations [59].

Another possible explanation for the correlation between magnesium and uric acid is that higher magnesium levels in semen may accelerate sperm metabolism resulting in increased formation of reactive oxygen species [59]. Further, a positive relationship was found between magnesium and interleukin-12, which is noted to have a pro-inflammatory property, and may contribute to the increased total oxidation status values. 
The variation between uric acid levels in blood and uric acid in semen was investigated, but not in profound detail. There were no significant differences in the level of uric acid in both seminal plasma and blood between subjects with normozoospermia and patients with abnormal semen parameters (e.g., oligoasthenozoospermia, asthenozoospermia, oligozoospermia, and cryptozoospermia) [60]. Such results are indicative of the equal importance of uric acid in semen and blood. In fact, the reabsorption mechanism of uric acid in kidneys is indicative of the importance of uric acid in the body; almost all (>99\%) filtrated uric acid by the glomerulus is reabsorbed in the proximal tubule back to the blood [61].

\section{Conclusions and Future Perspectives}

In summary, uric acid contributes to preserving and enhancing sperm motility, viability, and morphology, which in turn protects sperm function. This contribution is achieved principally by counteracting the damaging effect of oxidizing (e.g., reactive oxygen species and toxins) and nitrating agents. In addition, uric acid enhances certain bioactive enzymes that are vital for sperm function. In contrast, in certain circumstances, high levels of uric acid in semen may induce adverse effects to sperm function, this may occur by the reduction of the activity of vital seminal enzymes such as eNOS and CK. Additional research studies, mainly human studies, are still required to fully investigate the role of uric acid in semen and sperm function.

Funding: This research received no external funding.

Acknowledgments: This study was supported by the deanship of research at Jordan University of Science and Technology.

Conflicts of Interest: The authors declare no conflict of interest.

\section{References}

1. Becker, B.F. Towards the physiological function of uric acid. Free Radic. Biol. Med. 1993, 14, 615-631. [CrossRef]

2. Maiuolo, J.; Oppedisano, F.; Gratteri, S.; Muscoli, C.; Mollace, V. Regulation of uric acid metabolism and excretion. Int. J. Cardiol. 2016, 213, 8-14. [CrossRef] [PubMed]

3. Burtis, C.A.; Ashwood, E.R.; Bruns, D.E. Tietz Textbook of Clinical Chemistry and Molecular Diagnostics, 5th ed.; Elsevier: Amsterdam, The Netherlands, 2012.

4. Kim, S.C.; Kim, H.W. Effects of nitrogenous components of urine on sperm motility: An in vitro study. Int. J. Androl. 1998, 21, 29-33. [CrossRef] [PubMed]

5. Hirsch, I.H.; Jeyendran, R.S.; Sedor, J.; Rosecrans, R.R.; Staas, W.E. Biochemical analysis of electroejaculates in spinal cord injured men: Comparison to normal ejaculates. J. Urol. 1991, 145, 73-76. [CrossRef]

6. Ronquist, G.; Stegmayr, B.; Niklasson, F. Sperm motility and interactions among seminal uridine, xanthine, urate, and ATPase in fertile and infertile men. Arch. Androl. 1985, 15, 21-27. [CrossRef] [PubMed]

7. Ogino, N.; Yamamoto, S.; Hayaishi, O.; Tokuyama, T. Isolation of an activator for prostaglandin hydroperoxidase from bovine vesicular gland cytosol and its identification as uric acid. Biochem. Biophys. Res. Commun. 1979, 87, 184-191. [CrossRef]

8. Leone, E.; Santoianni, P. Nucleoside phosphorylase and adenosine deaminase in bull seminal vesicles. G. Biochim. 1957, 6, 226.

9. Petitjean, M.; Servouse, M. Comparative study of some characteristics of the semen of RR (rose comb) or rr (single comb) cockerels. Reprod. Nutr. Dev. 1981, 21, 1085-1093. [CrossRef] [PubMed]

10. Vince, S.; Zura Zaja, I.; Samardzija, M.; Majic Balic, I.; Vilic, M.; Duricic, D.; Valpotic, H.; Markovic, F.; Milinkovic-Tur, S. Age-related differences of semen quality, seminal plasma, and spermatozoa antioxidative and oxidative stress variables in bulls during cold and warm periods of the year. Animal 2018, 12, 559-568. [CrossRef] [PubMed]

11. Dzyuba, V.; Cosson, J.; Dzyuba, B.; Yamaner, G.; Rodina, M.; Linhart, O. The antioxidant system of seminal fluid during in vitro storage of sterlet Acipenser ruthenus sperm. Fish Physiol. Biochem. 2016, 42, 563-568. [CrossRef] [PubMed] 
12. Lochmiller, R.L.; Hellgren, E.C.; Varner, L.W.; Greene, L.W.; Amoss, M.S.; Seager, S.W.; Grant, W.E. Physiological responses of the adult male collared peccary, Tayassu tajacu (Tayassuidae), to severe dietary restriction. Comp. Biochem. Physiol. A Comp. Physiol. 1985, 82, 49-58. [CrossRef]

13. Ronquist, G.; Niklasson, F. Uridine, xanthine, and urate contents in human seminal plasma. Arch. Androl. 1984, 13, 63-70. [CrossRef] [PubMed]

14. Lewis, S.E.; Sterling, E.S.; Young, I.S.; Thompson, W. Comparison of individual antioxidants of sperm and seminal plasma in fertile and infertile men. Fertil. Steril. 1997, 67, 142-147. [CrossRef]

15. Rhemrev, J.P.; van Overveld, F.W.; Haenen, G.R.; Teerlink, T.; Bast, A.; Vermeiden, J.P. Quantification of the nonenzymatic fast and slow TRAP in a postaddition assay in human seminal plasma and the antioxidant contributions of various seminal compounds. J. Androl. 2000, 21, 913-920. [PubMed]

16. Lahnsteiner, F.; Mansour, N.; Plaetzer, K. Antioxidant systems of brown trout (Salmo truttaf. fario) semen. Anim. Reprod. Sci. 2010, 119, 314-321. [CrossRef] [PubMed]

17. Narayana, K.; Prashanthi, N.; Nayanatara, A.; Kumar, H.H.; Abhilash, K.; Bairy, K.L. Neonatal methyl parathion exposure affects the growth and functions of the male reproductive system in the adult rat. Folia Morphol. 2006, 65, 26-33.

18. Narayana, K. Methyl parathion induces the formation of symplasts by round spermatid fusion and alters the biochemical parameters in the testis. Morphologie 2007, 91, 173-179. [CrossRef] [PubMed]

19. Narayana, K.; Prashanthi, N.; Nayanatara, A.; Kumar, S.G.; Kumar, H.H.; Bairy, K.L.; D'Souza, U.J. A broad-spectrum organophosphate pesticide $O, O$-dimethyl $O$-4-nitrophenyl phosphorothioate (methyl parathion) adversely affects the structure and function of male accessory reproductive organs in the rat. Environ. Toxicol. Pharmacol. 2006, 22, 315-324. [CrossRef] [PubMed]

20. Prashanthi, N.; Narayana, K.; Nayanatara, A.; Chandra Kumar, H.H.; Bairy, K.L.; D'Souza, U.J. The reproductive toxicity of the organophosphate pesticide $O, O$-dimethyl $O$-4-nitrophenyl phosphorothioate (methyl parathion) in the male rat. Folia Morphol. 2006, 65, 309-321.

21. Poon, R.; Rigden, M.; Chu, I.; Valli, V.E. Short-term oral toxicity of pentyl ether, 1,4-diethoxybutane, and 1,6-dimethoxyhexane in male rats. Toxicol. Sci. 2004, 77, 142-150. [CrossRef] [PubMed]

22. Thiele, J.J.; Friesleben, H.J.; Fuchs, J.; Ochsendorf, F.R. Ascorbic acid and urate in human seminal plasma: Determination and interrelationships with chemiluminescence in washed semen. Hum. Reprod. 1995, 10, 110-115. [CrossRef] [PubMed]

23. Motrich, R.D.; Olmedo, J.J.; Molina, R.; Tissera, A.; Minuzzi, G.; Rivero, V.E. Uric acid crystals in the semen of a patient with symptoms of chronic prostatitis. Fertil. Steril. 2006, 85, 751.e1-751.e4. [CrossRef] [PubMed]

24. Hughes, C.M.; Lewis, S.E.; McKelvey-Martin, V.J.; Thompson, W. The effects of antioxidant supplementation during Percoll preparation on human sperm DNA integrity. Hum. Reprod. 1998, 13, 1240-1247. [CrossRef] [PubMed]

25. Zhang, H.Y.; Lu, J.C.; Zhang, R.S.; Xia, Y.X.; Huang, Y.F. Determination of uric acid in seminal plasma and correlation between seminal uric acid and semen parameters. Zhonghua Nan Ke Xue 2007, 13, 1016-1019. [PubMed]

26. Zhang, H.Y.; Lu, J.C.; Feng, R.X. Correlations of 24 biochemical markers in seminal plasma with routine semen parameters. Zhonghua Nan Ke Xue 2015, 21, 1087-1092. [PubMed]

27. Kutluyer, F.; Kayim, M.; Ogretmen, F.; Buyukleblebici, S.; Tuncer, P.B. Cryopreservation of rainbow trout Oncorhynchus mykiss spermatozoa: Effects of extender supplemented with different antioxidants on sperm motility, velocity and fertility. Cryobiology 2014, 69, 462-466. [CrossRef] [PubMed]

28. Srivastava, A.; Chopra, S.K.; Dasgupta, P.R. Biochemical analysis of human seminal plasma. II. Protein, non-protein nitrogen, urea, uric acid and creatine. Andrologia 1984, 16, 265-268. [CrossRef] [PubMed]

29. Xu, K.; Shang, X.; Chen, Y.; Zhao, F.; Zhu, P.; Huang, Y. Measurement of uric acid of seminal plasma in fertile and infertile males. Zhonghua Nan Ke Xue 2004, 10, 900-901, 906. [PubMed]

30. Rodriguez, P.C.; Beconi, M.T. Peroxynitrite participates in mechanisms involved in capacitation of cryopreserved cattle. Anim. Reprod. Sci. 2009, 110, 96-107. [CrossRef] [PubMed]

31. Beckman, J.S. Ischaemic injury mediator. Nature 1990, 345, 27-28. [CrossRef] [PubMed]

32. Kamat, J.P. Peroxynitrite: A potent oxidizing and nitrating agent. Indian J. Exp. Biol. 2006, 44, $436-447$. [PubMed] 
33. Degendorfer, G.; Chuang, C.Y.; Mariotti, M.; Hammer, A.; Hoefler, G.; Hagglund, P.; Malle, E.; Wise, S.G.; Davies, M.J. Exposure of tropoelastin to peroxynitrous acid gives high yields of nitrated tyrosine residues, di-tyrosine cross-links and altered protein structure and function. Free Radic. Biol. Med. 2018, 115, 219-231. [CrossRef] [PubMed]

34. Pietraforte, D.; Minetti, M. One-electron oxidation pathway of peroxynitrite decomposition in human blood plasma: Evidence for the formation of protein tryptophan-centred radicals. Biochem. J. 1997, 321 Pt 3, 743-750. [CrossRef] [PubMed]

35. Uribe, P.; Boguen, R.; Treulen, F.; Sanchez, R.; Villegas, J.V. Peroxynitrite-mediated nitrosative stress decreases motility and mitochondrial membrane potential in human spermatozoa. Mol. Hum. Reprod. 2015, 21, 237-243. [CrossRef] [PubMed]

36. Aitken, R.J.; Ryan, A.L.; Baker, M.A.; McLaughlin, E.A. Redox activity associated with the maturation and capacitation of mammalian spermatozoa. Free Radic. Biol. Med. 2004, 36, 994-1010. [CrossRef] [PubMed]

37. Andersen, J.K. Oxidative stress in neurodegeneration: Cause or consequence? Nat. Med. 2004, 10, S18-S25. [CrossRef] [PubMed]

38. Balercia, G.; Armeni, T.; Mantero, F.; Principato, G.; Regoli, F. Total oxyradical scavenging capacity toward different reactive oxygen species in seminal plasma and sperm cells. Clin. Chem. Lab. Med. 2003, 41, 13-19. [CrossRef] [PubMed]

39. Samarasinghe, S.; Krishnan, K.; Naidu, R.; Megharaj, M.; Miller, K.; Fraser, B.; Aitken, R.J. Parabens generate reactive oxygen species in human spermatozoa. Andrology 2018. [CrossRef] [PubMed]

40. Shi, T.Y.; Chen, G.; Huang, X.; Yuan, Y.; Wu, X.; Wu, B.; Li, Z.; Shun, F.; Chen, H.; Shi, H. Effects of reactive oxygen species from activated leucocytes on human sperm motility, viability and morphology. Andrologia 2012, 44 (Suppl. S1), 696-703. [CrossRef] [PubMed]

41. Chen, C.S.; Chao, H.T.; Pan, R.L.; Wei, Y.H. Hydroxyl radical-induced decline in motility and increase in lipid peroxidation and DNA modification in human sperm. Biochem. Mol. Biol. Int. 1997, 43, 291-303. [CrossRef] [PubMed]

42. Banihani, S.A. Vitamin B12 and Semen Quality. Biomolecules 2017, 7, 42. [CrossRef] [PubMed]

43. Campos Guillen, J.; Jones, G.H.; Saldana Gutierrez, C.; Hernandez-Flores, J.L.; Cruz Medina, J.A.; Valenzuela Soto, J.H.; Pacheco Hernandez, S.; Romero Gomez, S.; Morales Tlalpan, V. Critical minireview: The fate of tRNA(Cys) during oxidative stress in Bacillus subtilis. Biomolecules 2017, 7, 6. [CrossRef] [PubMed]

44. Stinefelt, B.; Leonard, S.S.; Blemings, K.P.; Shi, X.; Klandorf, H. Free radical scavenging, DNA protection, and inhibition of lipid peroxidation mediated by uric acid. Ann. Clin. Lab. Sci. 2005, 35, 37-45. [PubMed]

45. Sueishi, Y.; Hori, M.; Ishikawa, M.; Matsu-Ura, K.; Kamogawa, E.; Honda, Y.; Kita, M.; Ohara, K. Scavenging rate constants of hydrophilic antioxidants against multiple reactive oxygen species. J. Clin. Biochem. Nutr. 2014, 54, 67-74. [CrossRef] [PubMed]

46. Banihani, S.A. A Systematic review evaluating the effect of vitamin B6 on semen quality. Urol. J. 2017. [CrossRef]

47. Mostafa, T.; Rashed, L.; Taymour, M. Seminal cyclooxygenase relationship with oxidative stress in infertile oligoasthenoteratozoospermic men with varicocele. Andrologia 2016, 48, 137-142. [CrossRef] [PubMed]

48. Higashi, Y.; Maruhashi, T.; Noma, K.; Kihara, Y. Oxidative stress and endothelial dysfunction: Clinical evidence and therapeutic implications. Trends Cardiovasc. Med. 2014, 24, 165-169. [CrossRef] [PubMed]

49. Deby, C.; Deby-Dupont, G.; Noel, F.X.; Lavergne, L. In vitro and in vivo arachidonic acid conversions into biologically active derivatives are enhanced by uric acid. Biochem. Pharmacol. 1981, 30, 2243-2249. [CrossRef]

50. Donnelly, E.T.; Lewis, S.E.; Thompson, W.; Chakravarthy, U. Sperm nitric oxide and motility: The effects of nitric oxide synthase stimulation and inhibition. Mol. Hum. Reprod. 1997, 3, 755-762. [CrossRef] [PubMed]

51. Banihani, S.A. Histamine-2 receptor antagonists and semen quality. Basic Clin. Pharmacol. Toxicol. 2016, 118, 9-13. [CrossRef] [PubMed]

52. Miraglia, E.; De Angelis, F.; Gazzano, E.; Hassanpour, H.; Bertagna, A.; Aldieri, E.; Revelli, A.; Ghigo, D. Nitric oxide stimulates human sperm motility via activation of the cyclic GMP/protein kinase G signaling pathway. Reproduction 2011, 141, 47-54. [CrossRef] [PubMed]

53. Banihani, S.A.; Abu-Alhayjaa, R.F.; Amarin, Z.O.; Alzoubi, K.H. Pentoxifylline increases the level of nitric oxide produced by human spermatozoa. Andrologia 2018, 50, e12859. [CrossRef] [PubMed]

54. Banihani, S.A. Effect of paracetamol on semen quality. Andrologia 2018, 50, e12874. [CrossRef] [PubMed] 
55. Park, J.H.; Jin, Y.M.; Hwang, S.; Cho, D.H.; Kang, D.H.; Jo, I. Uric acid attenuates nitric oxide production by decreasing the interaction between endothelial nitric oxide synthase and calmodulin in human umbilical vein endothelial cells: A mechanism for uric acid-induced cardiovascular disease development. Nitric Oxide 2013, 32, 36-42. [CrossRef] [PubMed]

56. Banihani, S.A.; Abu-Alhayjaa, R.F. The activity of seminal creatine kinase is increased in the presence of pentoxifylline. Andrologia 2016, 48, 603-604. [CrossRef] [PubMed]

57. Durany, N.; Carreras, J.; Valenti, M.; Camara, J.; Carreras, J. Inactivation of phosphoglycerate mutase and creatine kinase isoenzymes in human serum. Mol. Pathol. 2002, 55, 242-249. [CrossRef] [PubMed]

58. Morin, L.G. Creatine kinase: Stability, inactivation, reactivation. Clin. Chem. 1977, 23, 646-652. [PubMed]

59. Kasperczyk, A.; Dobrakowski, M.; Zalejska-Fiolka, J.; Horak, S.; Birkner, E. Magnesium and selected parameters of the non-enzymatic antioxidant and immune systems and oxidative stress intensity in the seminal plasma of fertile males. Magnes. Res. 2015, 28, 14-22. [PubMed]

60. Guz, J.; Gackowski, D.; Foksinski, M.; Rozalski, R.; Zarakowska, E.; Siomek, A.; Szpila, A.; Kotzbach, M.; Kotzbach, R.; Olinski, R. Comparison of oxidative stress/DNA damage in semen and blood of fertile and infertile men. PLoS ONE 2013, 8, e68490. [CrossRef] [PubMed]

61. Garcia Puig, J.; Mateos Anton, F.; Munoz Sanz, A.; Gaspar, G.; Lesmes, A.; Ramos, T.; Ortiz Vazquez, J. Renal handling of uric acid in normal subjects by means of the pyrazinamide and probenecid tests. Nephron 1983, 35, 183-186. [CrossRef] [PubMed]

(C) 2018 by the author. Licensee MDPI, Basel, Switzerland. This article is an open access article distributed under the terms and conditions of the Creative Commons Attribution (CC BY) license (http:/ / creativecommons.org/licenses/by/4.0/). 